\title{
Effect of delignification process on physical properties of sugarcane baggase paper
}

Natalia Suseno, Lanny Sapei, Edy Purwanto, and Tokok Adiarto

Citation: AIP Conference Proceedings 1840, 080002 (2017); doi: 10.1063/1.4982300

View online: http://dx.doi.org/10.1063/1.4982300

View Table of Contents: http://aip.scitation.org/toc/apc/1840/1

Published by the American Institute of Physics

\section{Articles you may be interested in}

The effect of temperature and chitosan concentration during storage on the growth of chitosan nanoparticle produced by ionic gelation method

AIP Conference Proceedings 1840, 080001 (2017); 10.1063/1.4982299

The effects of surfactant and electrolyte concentrations on the size of nanochitosan during storage

AIP Conference Proceedings 1840, 080004 (2017); 10.1063/1.4982302

Synthesis of ACNT on quartz substrate with catalytic decomposition reaction from Cinnamomum camphora by using FC-CVD method

AIP Conference Proceedings 1840, 080003 (2017); 10.1063/1.4982301 


\title{
Effect of delignification Process on Physical Properties of Sugarcane Baggase Paper
}

\author{
Natalia Suseno ${ }^{1, a)}$, Lanny Sapei ${ }^{1, b)}$, Edy Purwanto ${ }^{1)}$,Tokok Adiarto ${ }^{2)}$ \\ ${ }^{1}$ Department of Chemical Engineering, University of Surabaya \\ ${ }^{2}$ Department of Chemistry, University of Airlangga \\ East Java, Surabaya, Indonesia \\ a)Corresponding author : suseno.natalia@yahoo.com \\ b)Lanny301@yahoo.com
}

\begin{abstract}
Wood fiber derived cellulose has been mainly used as the raw material in the papermaking. However, currently the paper production capacity is greater than the availability of wood. To overcome this problem, there have been many attempts to use non-wood fibers as substitutes for papermaking such as the fibrous materials derived from agriculture wastes. In this research, the paper was made from sugarcane bagasse which was previously delignified using soda process. The research was conducted by varying $\mathrm{NaOH}$ concentrations of $8-16 \%$, delignification temperatures of $60-$ $100^{\circ} \mathrm{C}$ and times of $30-150 \mathrm{~min}$. The aim of the research was to study the effect of delignification process on physical properties of sugarcane baggase soda pulping. The results showed the increase in tensile strengths as the $\mathrm{NaOH}$ concentrations increased. Tensile strength was increasing up to optimum temperature and time and then decreased. The water uptake results showed the opposite tendencies with those of tensile strength. The optimum condition was achieved at the $\mathrm{NaOH}$ concentration of $10 \%$, delignification temperature of $80^{\circ} \mathrm{C}$, and time of $90 \mathrm{~min}$. Tensile strength and water uptake achieved at this optimum condition were $27.42 \mathrm{~N} / \mathrm{mm}^{2}$ and $240 \mathrm{~g} / \mathrm{m}^{2}$, respectively.
\end{abstract}

Keywords : sugarcane baggase, soda delignification, tensile strength, water uptake

\section{INTRODUCTION}

The advent of new information and communication technology and the growing use of computers would lead to a decreased the use of paper worldwide. However pulp and paper products is one commodity that will continue to be consumed along with the growing population in the world. World paper demand is expected to grow by an average of 2.1 percent annually, while national pulp and paper industry is expected to continue to grow by $3-4 \%$ (CDR, Pulp and Paper Industry, 2013).

Non-wood fibers such as wheat, rice straw, corn husk, pine apple and baggase account for $5-7 \%$ of the total pulp and paper production worldwide. (R.W. Hurter, et.al., 2001; P.Zugenmaier, 2008). Production of pulp from nonwood resources has many advantages such as easy pulping capability, excellent fibers for the special types of paper. Non wood fibers have been investigated to be used as environmentally -benign alternatives to the use of trees due to its abundance as the sole effective source of cellulose fiber and cost effectiveness.

Bagasse is a by-product of the stem of sugar cane after crushing and juice extraction. Large quantity of bagasse

is produced annually and not much use is made of them except to incinerate. Use of bagasse will lead to conversion of waste to wealth especially for pulp and paper making. Bagasse contains $52.42 \%$ cellulose, $25.8 \%$ hemicellulose and $21.69 \%$ lignin (A.Samariha and A.Khakifirooz, 2011). The cellulose content is high enough to be used for paper making. The production of paper is essentially a process of removing the lignin contained in the fiber of raw materials, in order to obtain a high cellulose content and low lignin content in pulp or paper (D.Fengel. and G.Wegener, 1995). The soda process has been known to be the older and simplest pulping process. It is a also applicable to leafy and conifer wood, as well as to non-wood raw material such as agricultural residues (A.Rodriguez,et al.,2010).

Research of papermaking from bagasse with a variety of processes and additional raw materials have been done by several researchers, among others: organosolv and alcohol pulping of baggase (M.El-Sakhawy,et al., 1995), the

\footnotetext{
International Seminar on Fundamental and Application of Chemical Engineering 2016 (ISFAChE 2016)

AIP Conf. Proc. 1840, 080002-1-080002-6; doi: 10.1063/1.4982300
}

Published by AIP Publishing. 978-0-7354-1510-2/\$30.00 
soda twice delignification for soda and kraft pulping (Doherty,et al., 2006), delignification of sugarcane baggase with alkali and peracetic acid (Xuebing Zhao,et al., 2010), sugarcane baggase conversion to high refined cellulose using nitric acid, sodium hydroxide and hydrogen peroxide as the delignificating agents (S.Supranto, et al.,2015).

Paper products use depends on the strength properties of the paper. The strength of paper depends on the fiber length and the method of pulping process used. In spite of much study in non-wood pulping, little research has been conducted on the pulping of sugarcane baggase by soda process in order to study the physical properties (tensile strength and water uptake) in relation with the delignification process condition. Therefore the aim of this experiment is to study the effect of soda delignification process ( $\mathrm{NaOH}$ concentration, temperature, time) to the paper sheet physical properties ( tensile strength and water uptake). It was also to establish the optimum operating pulping conditions.

\section{METHODOLOGY}

\section{Soda Pulping Process}

The wastes of sugarcane bagasse from juice were used for the pulping process. In the delignification process of sugar cane various $\mathrm{NaOH}$ concentration $(8,10,12,14,16) \%$, delignification temperature $(60,70,80,90,100)^{\circ} \mathrm{C}$ and time $(30,60,90,120,150)$ min were varied. Delignified sugarcane baggase was mixed with $\mathrm{NaOH}$ with a ratio

$1: 12(\mathrm{w} / \mathrm{v})$ in a laboratory flask. The resulting pulp were neutralized by washing with water. Delignified sugarcane baggase was added with water and blended with motor stirrer in $500 \mathrm{rpm}$. The mixtures were poured into a filter and pressed by water aided by a gravity force to remove out water. The resulting cake was a sheet of paper which was then dried in the oven for further characterization.

\section{Paper characterizations}

Several characterization, such as the measurement of tensile strength and water uptake, as well determination was conducted.Tensile strength was measured using an autograph. A small piece of paper was pulled with an increased force until it was broken. The obtained tensile strength was recorded from the monitor (TAPPI T-404).

For the water uptake measurement, a piece of paper was put into the instrument and then $100 \mathrm{ml}$ water was added an held for 1 minute. Paper was vibrated to remove the water in the surface and then was weighed water uptake percentage was calculated as the ratio of difference in weight after and before to water absorbed area (SNI 0499:2008)

\section{Optimization of the Soda Pulping Process}

The optimum condition in the delignification process was determined using the response surface methods. In this method, input variables and output variables were modelled using a second order polynomial equation.

$$
Y_{1}=\beta o+\beta_{1} . X_{1}+\beta_{2} X_{2}+\beta_{11} X_{1}^{2}+\beta_{22} X_{2}^{2}+\beta_{12} X_{1} . X_{2}
$$

where $\mathrm{X}_{1}$ and $\mathrm{X}_{2}$ are independent or input variables, i.e. $\mathrm{NaOH}$ concentration, delignification temperature and time. $\mathrm{Y}_{\mathrm{i}}($ $\mathrm{i}=1-2)$ is the response or output variables, i.e. tensile strength and water uptake. $\beta$ o is a constant, $\beta_{1}$ and $\beta_{2}$ represent the linear coefficients, whilst $\beta_{11}$ and $\beta_{22}$ are the quadratic coefficients, $\beta_{12}$ is the interaction coefficients,

Result of physical test were analysed by statistic with $95 \%$ significance level. The software Microsoft Excel was performed to analyse the results in the form of analysis of variance (ANOVA). The data analysis in the Microsoft Excel software was performed for regression whereas Matlab software was employed to visualize the results. 


\section{RESULTS AND DISCUSSION}

In this soda delignification process, $\mathrm{NaOH}$ concentration, temperature and time were varied in order to obtain the optimum condition. In Table 1, fifteen experiments conducted, together with the delignification conditions and their corresponding paper physical properties (tensile strength and water uptake). For each variables such as $\mathrm{NaOH}$ concentration and its corresponding variables such as delignification temperatures, the tensile strength $Y_{1}$ and water uptake $\mathrm{Y}_{2}$ were determined.

The correlation of the response $Y_{1}$ and $Y_{2}$ to independent variables was estimated by multiple linear regressions. The obtained regression coefficient and analysis of variance (ANOVA) were depicted in Table 2 and Table 3 . The

experimental data (Table 1) was fitted with a second-order polynomial model by performing multiple linear regressions (equation 2,3).

TABLE 1. Effect of Process Conditions on Tensile Strength

\begin{tabular}{ccccc}
\cline { 1 - 1 } $\begin{array}{c}\mathrm{C}_{\mathrm{NaOH}} \\
(\%)\end{array}$ & $\begin{array}{c}\text { Temperature } \\
\left({ }^{\circ} \mathrm{C}\right)\end{array}$ & $\begin{array}{c}\text { Time } \\
(\mathrm{min})\end{array}$ & $\begin{array}{c}\text { Tensile Strength } \\
\left(\mathrm{N} / \mathrm{mm}^{2}\right)\end{array}$ & $\begin{array}{c}\text { Water uptake } \\
\left(\mathrm{g} / \mathrm{m}^{2}\right)\end{array}$ \\
\hline 8 & 90 & 90 & 8.73 & 360 \\
10 & 90 & 90 & 18.8 & 270 \\
12 & 90 & 90 & 7.10 & 340 \\
14 & 90 & 90 & 6.21 & 370 \\
16 & 90 & 90 & 4.57 & 400 \\
10 & 60 & 90 & 8.07 & 390 \\
10 & 70 & 90 & 13.15 & 360 \\
10 & 80 & 90 & 26.43 & 240 \\
10 & 90 & 90 & 18.86 & 290 \\
10 & 100 & 90 & 5.30 & 400 \\
10 & 80 & 30 & 11.07 & 320 \\
10 & 80 & 60 & 18.56 & 250 \\
10 & 80 & 90 & 27.42 & 240 \\
10 & 80 & 120 & 21.94 & 260 \\
10 & 80 & 150 & 16.96 & 330 \\
\hline
\end{tabular}

\section{Effect of Temperature, $\mathrm{NaOH}$ Concentration and Time on Tensile strength}

The correlation between tensile strength $\left(\mathrm{Y}_{1}\right)$ and the two independent variables each for $\mathrm{NaOH}$ concentration and temperature, $\mathrm{Na} \mathrm{OH}$ concentration and time, temperature and time were showed in Table 2

TABLE 2. Significance of Regression Coefficients for Tensile Strength

\begin{tabular}{|c|c|l|r|l|}
\hline & Coefficients & $\begin{array}{l}\text { Standard } \\
\text { Error }\end{array}$ & t Stat & p-value \\
\hline Intercept & 40.58 & 10.89 & 3.73 & $5.82 \times 10^{-3}$ \\
\hline $\mathrm{X}_{1}^{2}$ & $-4.33 \times 10^{-1}$ & $3.30 \times 10^{-1}$ & -1.31 & $2.27 \times 10^{-1}$ \\
\hline $\mathrm{X}_{2}{ }^{2}$ & $-4.22 \times 10^{-2}$ & $1.17 \times 10^{-2}$ & -3.60 & $7.00 \times 10^{-3}$ \\
\hline $\mathrm{X}_{3}{ }^{2}$ & $-2.12 \times 10^{-3}$ & $1.26 \times 10^{-3}$ & -1.69 & $1.30 \times 10^{-1}$ \\
\hline $\mathrm{X}_{1} \mathrm{X}_{2}$ & $3.41 \times 10^{-1}$ & $9.84 \times 10^{-2}$ & 3.47 & $8.48 \times 10^{-3}$ \\
\hline $\mathrm{X}_{1} \mathrm{X}_{3}$ & $-2.43 \times 10^{-1}$ & $9.30 \times 10^{-2}$ & -2.62 & $3.05 \times 10^{-2}$ \\
\hline $\mathrm{X}_{2} \mathrm{X}_{3}$ & $3.59 \times 10^{-2}$ & $1.25 \times 10^{-2}$ & 2.87 & $2.08 \times 10^{-2}$ \\
\hline
\end{tabular}

The influence of the temperature $\left(\mathrm{X}_{2}{ }^{2}{ }_{2}\right)$ on tensile strength during the delignification process was statistically significant $(\mathrm{p}<0.05)$ in contrast to the influence of $\mathrm{NaOH}$ concentration $\left(\mathrm{X}_{1^{2}}\right)$ and time $\left(\mathrm{X}_{3}\right)$ which $\mathrm{p}>0.05$. 
Furthermore, the tensile strength of the resulting paper followed the quadratic function of temperature $(\mathrm{p}<0.05)$ as shown in equation $(2)$.

$$
\begin{aligned}
\mathrm{Y}_{1}= & 40.58-4.33 .10^{-1} \mathrm{X}_{1}^{2}-4.22 .10^{-2} \mathrm{X}_{2}^{2}-2.12 .10^{-3} \mathrm{X}_{3}^{2}+3.41 .10^{-1} \mathrm{X}_{1 .} . \\
& -2.43 .10^{-1} \mathrm{X}_{1} \mathrm{X}_{3}+3.59 .10^{-2} \mathrm{X}_{2} \mathrm{X}_{3}
\end{aligned}
$$

The correlation between tensile strength $\left(\mathrm{Y}_{1}\right)$ to the two independent variables ( $\mathrm{NaOH}$ concentration and temperature) after applying of response surface methodology can be represented by Figure 1 .

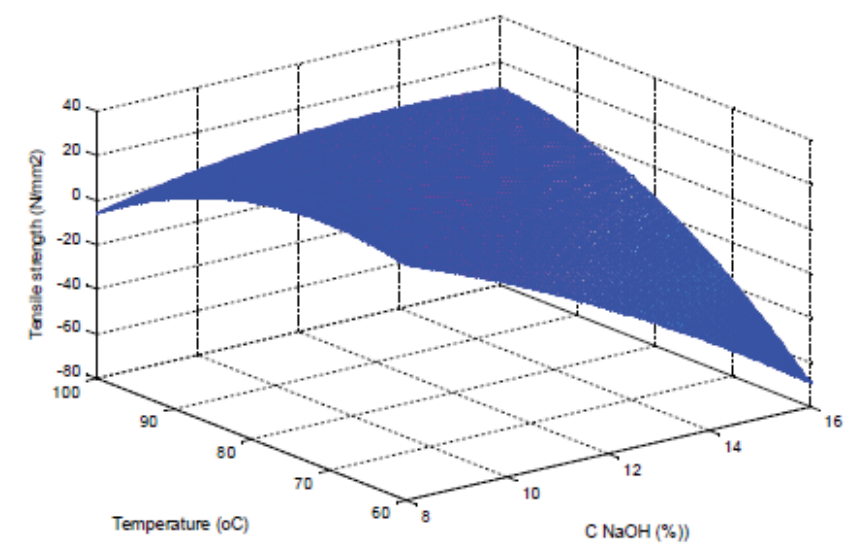

FIGURE 1. Tensile Strength versus $\mathrm{NaOH}$ concentration and temperature at optimum time (90min)

Tensile strength was generally influenced by the fiber length and molecular bonds. The longer the cellulose fibers and the stronger the molecular bonds are, the higher the tensile strengths of the paper. Removal of lignin in the cell will increase the molecular bonding between cellulose fibers, thus increasing the tensile strength (Haygreen and Bowyer, 1996; L.Sapei, et al., 2014). The higher the concentration of $\mathrm{NaOH}$, the more lignin could be dissolved. However the possibility of the cellulose fibers degradation is increased as $\mathrm{NaOH}$ concentration increased at the certain temperature and time (E.Sjostrom, 1995; L.Sapei et al, 2014). This was the reason of the tensile strength decrease when $\mathrm{NaOH}$ concentration above $10 \%$ was used.

\section{Effect of $\mathrm{NaOH}$ Concentration, Temperature and Time on water uptake}

The resistance of paper against water uptake is another important characteristic of used paper. The experimental data (Table 1.) was fitted with a second-order polynomial model by performing multiple linear regressions (Eq. 3). The correlation between water $\left(\mathrm{Y}_{2}\right)$ and the two independent variables each for $\mathrm{NaOH}$ concentration and temperature, $\mathrm{NaOH}$ concentration and time, temperature and time were showed in Table 3.

TABLE 3. Significance of Regression Coefficients for Water Uptake

\begin{tabular}{|c|c|c|c|c|}
\hline & Coefficient & $\begin{array}{c}\text { Standar } \\
\mathrm{d}\end{array}$ & $\mathrm{t}$ Stat & $\mathrm{p}$-value \\
\hline Intercept & 132.16 & 74.51 & 1.77 & $1.14 \times 10^{-1}$ \\
\hline $\mathrm{X}_{1}{ }^{2}$ & 4.42 & 2.26 & 1.95 & $8.66 \times 10^{-2}$ \\
\hline $\mathrm{X}_{2}{ }^{2}$ & $3.64 \times 10^{-1}$ & $8.02 \times 10^{-2}$ & 4.54 & $1.90 \times 10^{-3}$ \\
\hline $\mathrm{X}_{3}{ }^{2}$ & $1.61 \times 10^{-2}$ & $8.61 \times 10^{-3}$ & 1.86 & $9.92 \times 10^{-2}$ \\
\hline $\mathrm{X}_{1} \mathrm{X}_{2}$ & -3.15 & $6.73 \times 10^{-1}$ & -4.68 & $1.57 \times 10^{-3}$ \\
\hline $\mathrm{X}_{1} \mathrm{X}_{3}$ & 2.10 & $6.36 \times 10^{-1}$ & 3.31 & $1.08 \times 10^{-2}$ \\
\hline $\mathrm{X}_{2} \mathrm{X}_{3}$ & $-2.98 \times 10^{-1}$ & $8.55 \times 10^{-1}$ & -3.48 & $8.32 \times 10^{-3}$ \\
\hline
\end{tabular}

The influence of the temperature $\left(\mathrm{X}_{2}{ }^{2}\right)$ on water uptake during the delignification process was statistically significant $(\mathrm{p}<0.05)$ in contrast to the influence of $\mathrm{NaOH}$ concentration $\left(\mathrm{X}_{1}{ }^{2}\right)$ and time $\left(\mathrm{X}_{3}{ }^{2}\right)$ which $\mathrm{p}>0.05$. Furthermore, the tensile strength of the resulting paper followed the quadratic function of temperature $(\mathrm{p}<0.05)$ as shown in equation (3). 


$$
\mathrm{Y}_{2}=132.16+4.42 \mathrm{X}_{1}^{2}+3.64 .10^{-1} \mathrm{X}_{2}^{2}+1.61 \cdot 10^{-2} \mathrm{X}_{3}^{2}-3.15 \mathrm{X}_{1} \mathrm{X}_{2}+2.10 \mathrm{X}_{1} \mathrm{X}_{3}-2.98 .10^{-1} \mathrm{X}_{2} \mathrm{X}_{3}
$$

The correlation between water uptake $\left(\mathrm{Y}_{2}\right)$ to the two independent variables ( $\mathrm{NaOH}$ concentration and temperature) after applying of response surface methodology can be represented by Figure 2 .

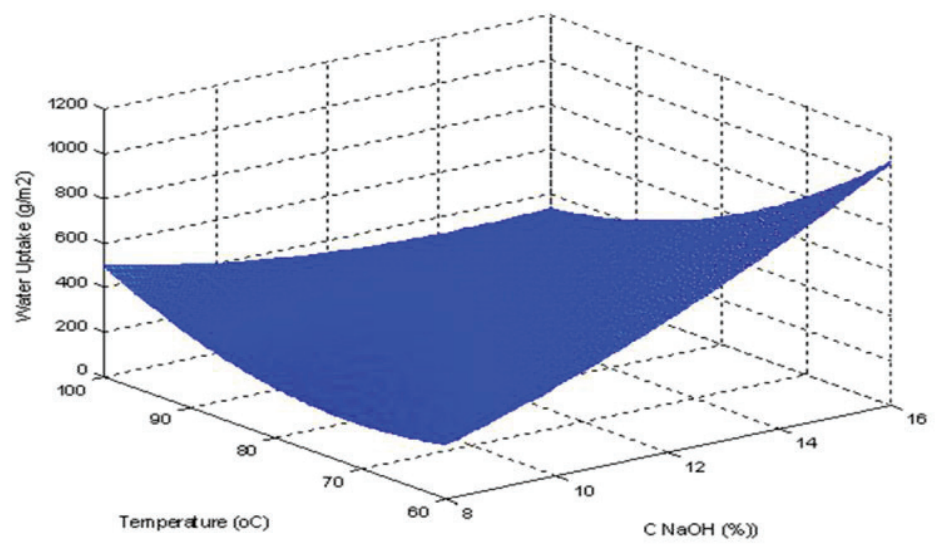

FIGURE 2. Water Uptake versus $\mathrm{NaOH}$ concentration and temperature at optimum time (90min)

The same trend was observed by the variations in delignification temperature. The increase in temperature would increase the delignification process thus increasing the tensile strength in the certain $\mathrm{NaOH}$ concentration and time. However, above the optimum temperature, tensile strength decreased due to the increasing depolymerisation of cellulose fibers though delignification process was accelerated. High temperature enhanced the solubilisation of polysaccharide chains (D.Fengel and G.Wegener, 1995).

\section{CONCLUSION}

The results showed the increase in tensile strengths as the $\mathrm{NaOH}$ concentrations increased. Tensile strength was increasing up to certain temperature and time and then decreased. The water uptake results showed the opposite tendencies with those of tensile strength. The optimum condition was achieved at the $\mathrm{NaOH}$ concentration of $10 \%$, delignification temperature of $80{ }^{\circ} \mathrm{C}$, and time of $90 \mathrm{~min}$. Tensile strength and water uptake achieved at this optimum condition were $27.42 \mathrm{~N} / \mathrm{mm}^{2}$ and $240 \mathrm{~g} / \mathrm{m}^{2}$, respectively.

\section{ACKNOWLEDGMENTS}

The authors wish to thank Ms. Puspita Rahayu and Ms.Moses Evan Joseph for the work assistance. We also thank Ms. Dyah Ayu Ambarsari for the technical assistance during the experiments conducted at Polymer and Membrane Laboratory of Surabaya University, East Java, Indonesia. 


\section{REFERENCES}

1. Comercial Global Data Research (CDR), "Pulp \&Paper Industry In Indonesia", 2013 $<$ http://commercialglobaldatarearch.co.id/2013/pulp-paper> accessed on August 5, 2016

2. R.W. Hurter and M.V. Byrd. "Process for Producing a Pulp Suitable for Papermaking from Nonwood Fibrous Materials". US 6,302,997 B1 (October 16, 2001).

3. P. Zugenmaier, Crystalline Cellulose and Derivates, Characterization and Structures, Spinger Series in Wood Science", Verlag Berlib Heidelberg, Jerman,(2008)

4. A.Samariha dan A.Khakifrooz, Application of NSSC Pulping to Sugarcane Bagasse, Bioresource. Hal.., 2011), p.p 3313-3323

5. D.Fengel and G.Wegener, Kayu: Kimia, Ultrastruktur, Reaksi-reaksi. Gajah Mada University Press. Yogyakarta, Indonesia, 1995.

6. A.Rodríguez, R.Sánche, A.Requejo, and A.Ferrer, Feasibility of Rice Straw as a Raw Material for The Production of Soda Cellulose Pulp, Journal of Cleaner Production, 18(10), 2010), p.p1084-1091

7. M.El-Sakhawy, Y.Fahmy, A.A. Ibrahim, B.Lonnberg, Organosolv pulping, Alcohol pulping of baggase. Cellulose Chemistry and Technology, 29, 1995), p.p 615-629

8. W.O.S Doherty and T.J. Rainey, M10 Bagasse Fractionation by the Soda Process in Hogarth, Proceedings of the Australian Society of Sugar Cane Technologiests ,Australia Queensland University of Technology. 2006

9. Z.Xuebing, Evert v.d Hyde, Ting Zhang, L.Dehua, Delignification of Sugarcane Bagasse With Alkali and Peracetic Acid and Charaterization of the Pulp, BioResources 5(3), 2010), pp. 1565-1580

10. S.Supranto, A. Tawfiequrrahman, D.E. Yunanto, Sugarcane Bagasse Conversion to High Refined Cellulose Using Nitric Acid, Sodium Hydroxide and Hydrogen Peroxide As The Delignificating Agents, Journal of Engineering Science and Technology Special Issue on SOMCHE 2014\&RSCE 2014 Conference, School of Engineering Taylor's University, (2015), pp.35-46

11. TAPPI T-404. "Cara Uji Kekuatan Tarik Kertas." Badan Standarisasi Nasional

12. SNI 0499:2008 : Kertas dan Karton, Uji Daya Serap Air, Metode Cobb, 2008

13. J.G.Haygreen, and Bowyer. Hasil Hutan dan Ilmu Kayu. Gajah Mada University Press. Yogyakarta, Indonesia, 1996.

14. Sjostrom. Kimia Kayu. Edisi 2. Dasar-dasar dan Penggunaan, terjemahan H. Sastrohamidjojo ,Gadjah Mada University Press. Yogyakarta, Indonesia, 1995.

15. L. Sapei; E. Purwanto.; N.Suseno., Two Step Soda Pulping Process of Rice Straw for The Recycle Papermaking, Chemical Engineering Department, Proceeding of Bali International Seminar on Science and Technology (BISTECH) II, 2014 